\title{
INNOVATIVE LOCAL POLICIES IN PORTUGUESE LOW-DENSITY RURAL AREAS
}

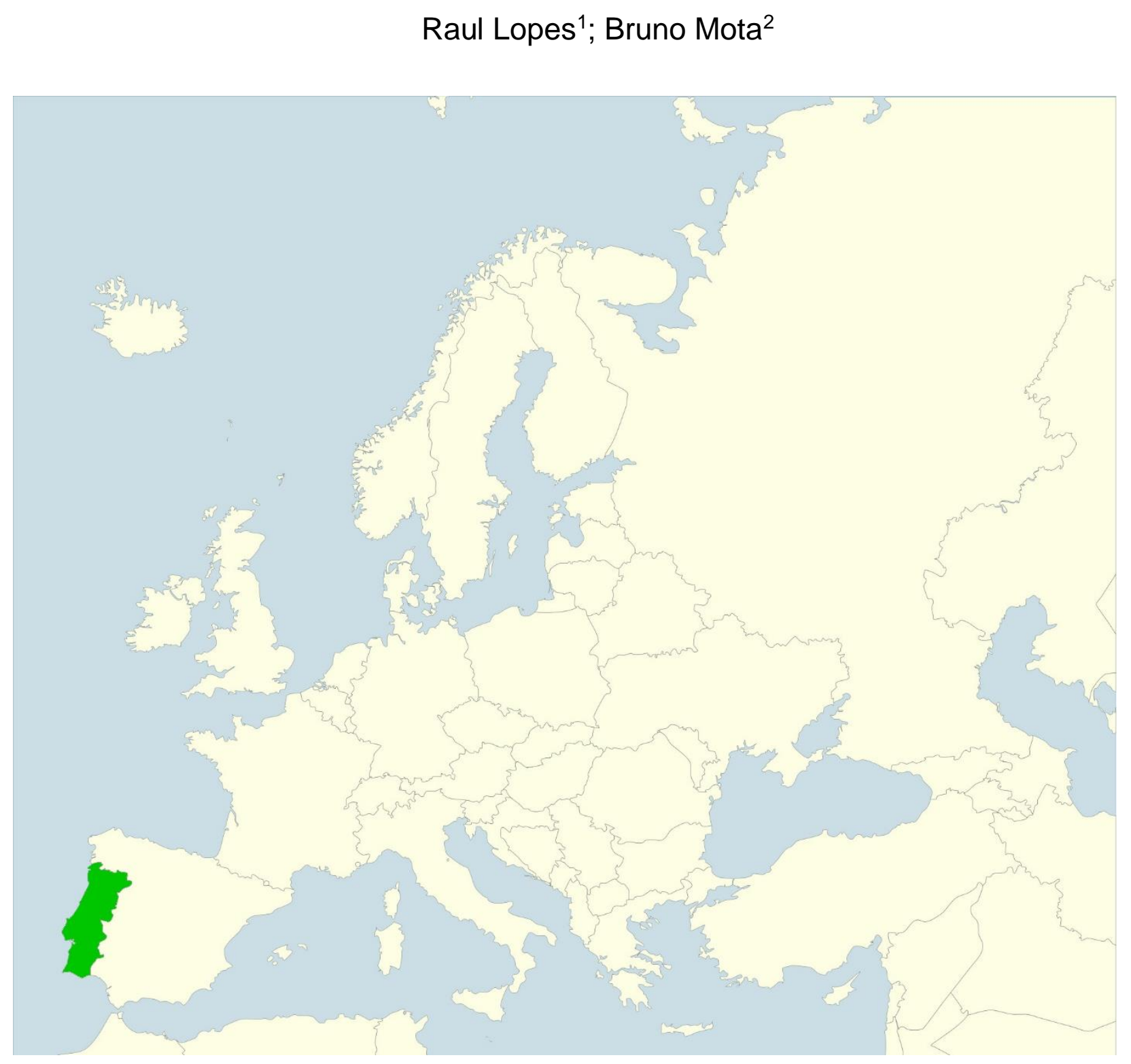

${ }^{1}$ ICSTE - Instituto Universitário de Lisboa, Lisboa, Portugal, e-mail: Raul.lopes@iscte-iul.pt, ORCID: 0000-0001-9411$863 X$

2 Universidade de Lisboa, Lisboa, Portugal 
Abstract: Nowadays, the issue of rural development has a central place on the agenda of policymakers, prompting a discussion on the instrumental and procedural options of public policies. This paper seeks to contribute to the reflection on the potentialities and limitations of promoting rural development based on innovative strategies sustained by territorial governance modalities, which entail an active involvement of local agents, especially local authorities. For this, it takes as case studies three public policy experiences led by local authorities within a Portuguese low-density region, with one of the lowest development rates among EU regions. Specifically, it aims to discuss: (a) the effectiveness of adopting innovative policies in the context of low-density rural areas; and (2) the role of territorial governance in the success of those policies. The research followed a document analysis and interviews with local development actors. The analysis suggests that peripheral rural areas are not condemned to human desertification. There is a wide spectrum of opportunities for these areas. They can bring together a strategic view of the future, and an institutional leadership capable of dynamizing an adjusted territorial governance model. This is the challenge currently facing rural development policy.

Keywords: Rural development policy, Innovative local policies, low-density rural areas, local authority action, Portugal

Resumo: No séc. XXI o paradigma territorialista emergiu como quadro teórico-conceptual do desenvolvimento, levando ao questionar das políticas territoriais entretanto adotadas, em especial do seu modelo de governança territorial. É neste contexto que a problemática do desenvolvimento rural tem vindo a ocupar um lugar central na agenda dos policy makers, suscitando a discussão sobre as opções instrumentais e processuais das políticas públicas a adotar. $O$ presente texto inscreve-se justamente no propósito de contribuir para a reflexão sobre as potencialidades e limitações da promoção do desenvolvimento rural a partir de estratégias inovadoras alicerçadas em modalidades de governança territorial com envolvimento ativo dos agentes locais, especialmente das autarquias locais. Tendo como pano de fundo uma região remota de baixa densidade em Portugal, que tem um dos menores índices de desenvolvimento de entre as regiões da EU, analisam-se aqui três experiências de políticas públicas lideradas por autarquias locais, com o propósito de: por um lado, discutir a eficácia da adoção de políticas inovadoras no contexto de espaços rurais de baixa densidade; por outro lado, discutir o papel da governança territorial no sucesso daquelas políticas. Como corolário da nossa pesquisa conclui-se que os espaços rurais periféricos não estão condenados à desertificação humana, há um largo espetro de oportunidades para estes espaços, assim neles se consiga fazer convergir uma visão estratégica de futuro, e liderança institucional capaz de dinamizar um ajustado modelo de governança territorial. Este é o desafio que se coloca atualmente à política de desenvolvimento rural.

Palavras chave: Política de Desenvolvimento Rural; Políticas Locais Inovadoras; Espaços rurais de baixa densidade; Autarquias Locais; Portugal

\section{Highlights:}

- Our research is framed by rural development theories, with special emphasis on societal innovation and territorial governance. The main goal is to clarify how local authorities can promote the development of contexts that appeared to be doomed to desertification.

- In rural areas, the agricultural activity no longer has the relevance that it had in the past, such that living in rural areas does not mean working the land. This new reality, questions past rural development policies based on agricultural modernization. Not surprisingly in our successful cases, the most recent rural development policy paradigm was adopted. 
- Our study shows that peripheral rural areas are not condemned to desertification. In line with OCDE (2020), our case studies suggest there is a wide range of possibilities for local development stemming from bottom-up approaches.

- The promotion of local competitiveness claims capacity for innovation, of market and societal, anchored on the combination of endogenous with exogenous potentialities. This requires a strategic vision of the future and institutional leadership.

- The success of local development policies is inextricably linked to the territorial governance model adopted. A weak model of governance leads to a failed strategy. The success of a development strategy requires a multilevel governance model, where local authorities promote stakeholders' networking and innovation.

\section{Introduction}

Urban areas have become home to $55 \%$ of the world's population, a proportion expected to continuously grow over the years (Guterres, 2020). Nevertheless, policy makers have never before given serious attention to the issue of rural development as in this century, due to the challenges presented by globalisation to public policies. Nowadays, agricultural activity no longer has the economic and social relevance that it had in the past, such that living in rural areas does not mean working the land. This new reality, questions past rural development policies based on agricultural modernization and the paradigm of economic growth (e.g., OECD, 2020; Dax \& Fischer, 2018).

In the 1980s, a new theoretical approach to territorial development emerged, which will become a central paradigm in the literature, during the $21^{\text {st }}$ century - the territorial paradigm (Pike, Rodríguez-Pose, and Tomaney, 2017), relying on innovation as the key factor for regional development. As pointed out by Gurria (2007), "Innovation is often wrongly considered as a synonymous of "high-tech activity" and R\&D, which are mostly carried out in urban areas. Rural regions may find it much harder to compete in the production of emerging technologies than in the development of mature technologies and alternative methods. Thus, the capacity of each territory to innovate depends on the potential of interaction inherent to its economic basis, and from their model of territorial governance. This requires leadership capacity at the local level.

Alongside, a new political approach to territorial development emerges: the place-based policy paradigm. The convergence of these two new paradigms will ground the current general characterisation of rural development. It is within such theoretical-conceptual framework that the debate around new forms of rural development has been conducted in the literature, focusing the discussion on the best suited instrumental and procedural options of public policies (e.g., Capello, 2016). It is thus important to better understand the potential and limitations of promoting rural development based on innovative strategies anchored on territorial governance modalities with the active involvement of local development agents, especially local authorities. For this, the present paper focuses on three Portuguese low-density rural areas, located in a region with one of the lowest development rates among EU regions. It offers relevant insights on the current territorial debate, drawing on the role of local institutions and authorities, to enable innovative development policies in such areas. In summary, by focusing on three case studies, this paper has two main aims: (1) to discuss the effectiveness of adopting innovative policies in the context of low-density rural areas; and (2) to discuss the role of territorial governance in the success of those policies.

Theoretically, this paper draws from the approaches of rural development, societal innovation, and territorial governance. It assumes that understanding local development processes in socioterritorial adverse contexts requires looking at the governance ability of municipalities.

Before continuing, we need to define "low-density rural areas" a central concept in this paper. "Low-density rural areas" can also be considered as "deep rural areas", "marginal areas", "remote areas" or "peripheral rural areas" (Ferrão, 2000; CEMAT, 2007; OCDE, 2020). The economic basis of such areas relies on traditional agriculture and personal and collective services. These are also areas characterised by an ageing population and a low demographic density. These 
areas are further compounded by a reduced institutional thickness, a weak network of local actors, whether public, business, or associative, and a peripheral economic and geographical positioning concerning large urban centres and global markets.

The next section provides a brief theoretical review on the definition of "rural" and, particularly, on the policies of regional and rural development. Linked with this issue, we clarify the understanding of innovation in the context of this research. We also underline the relevance of territorial governance to promote societal innovation and to assure local development within a background devoid of institutional tissue, as it usually happens in remote rural areas. Section 3 offers an overview over the history of rural policies in Portugal, and presents the methodology used, the analysis undertaken and the respective results. In section 4, results are discussed drawing on the territorial paradigm of development (Pike et al., 2017) and the place-based policy paradigm (Fermisson, 2000, Vázquez-Barquero, 2010, Ferrão, 2015). Finally, some conclusions are drawn from the case studies, and their potential implications for rural development policies are underlined.

\section{Rural development policy: from the focus on agriculture to the centrality of innovation, networking and multilevel territorial governance}

\subsection{The background: rural, a changing concept}

Until the middle of the 20th century, rural areas were conceptualized as mere remaining areas, archaic spaces, that is, undeveloped, and overpopulated. Impelled by such conceptualization, public policies did not assume rural area as an object of study (Calatrava, 2016:6). The transformations in rural areas were primarily seen as the result of urban dynamics.

After the Second World War, the concept of rural was no longer seen as an "archaic space", but instead as "what is not urban", remaining without an individual identity (Ferrão \& Lopes, 2004). In this period, the main changes in rural areas stemmed from the industrialization policies in progress, which needed labour, that was scarce in the cities. The mechanization of agricultural holdings, large public investments in infrastructures to support agriculture (e.g., electrification, irrigation, roads) and the macroeconomic promotion of accelerated growth, characterised the public policies adopted in the decades following World War II.

Meanwhile, political authorities, particularly in France, became aware that the process of macroeconomic growth was accentuating the asymmetries between urban and rural areas (e.g., Aydalot, 1980). As a result, some countries began to focus on correcting regional inequities, by developing public policies oriented to provide rural areas with sociocultural facilities. The sociocultural dimension of rural communities would then become a central aspect of rural development policies in the EU after the 1980s. Following this, during the 1980s and the 1990s, multiple endogenous regional development approaches emerged (Aydalot, 1986; Benko \& Lipietz, 1992; Saxenian, 1994; Stöhr, 1980 and 1986; Vázquez-Barquero, 1993) settling the ground to a new paradigm of territorial development policies. This criticizes the functional, exogenous and spatial distributive scope of previous regional policies, arguing that effective policymaking should be structured from the local level. Specifically, it should focus on the valorisation of the endogenous' potentialities of development and the mobilization of local actors, under the political leadership of entities endowed with political legitimacy from the community. Hence, development policies must be framed by a systemic vision where the rural territory has its own identity, becoming a multidimensional space (Ferrão \& Lopes, 2004).

In the first two decades of the 21st century, rural areas re-emerged as a central issue for development policies (see OECD, 2003, 2006, 2013, 2016, 2018 and 2020). The scope of the rural problem was no longer agriculture. The turn of the century marks the moment when most of the population living in rural areas have no economic connection to agricultural activity (OECD, 2003). In summary, these areas are less developed than urban areas, and face strong competitive handicaps due to their fragile (and aged) social fabric and weak relational network among their actors. But they have development potential too, as we will see below. 


\subsection{Rural innovation: from business-oriented innovation to societal innovation}

Innovation has been receiving the attention of economists since the beginning of the 20th century, when Schumpeter (1911) published The Theory of Economic Development. Since then, and especially after OECD \& Eurostat (1997) published the Oslo Manual - offering a methodology to measure innovation, innovation has been a prominent issue in the international literature. The literature suggests that innovation adds value to different activities, stemming from a multidimensional process with an impact on the product, the process, and at the organizational and/or marketing level (OECD \& Eurostat,1997).

Drawing on the pioneering work of Porter (1990), the approach of innovation has extended from companies to sectors of activity, regions, and countries. Specifically, it focuses on understanding countries and regions' competitiveness in the light of innovation, rather than drawing on the cost of production. This paradigmatic shift had profound implications for the economic theory of the development of territories and rural areas. Territorial competitiveness began to be defined accordingly to the regions' specificities within the context of the global market, and not to what regions produced cheaper (Lopes, 2001). "Milieu innovateur" (Aydalot, 1986; Maillat, 1995); "Learning Region" (Morgan, 1997; Moulaert \& Sekia, 2003; Perry, 2014; Füg \& lbert, 2020); "Regional Innovation Systems" (Cooke, 2001); "Innovation modes" (Jensen et al., 2007; Nunes \& Lopes, 2015); "Regional Smart Specialization" (Foray, 2015; Asheim, 2019) are some of the recurring concepts in the literature on territorial development. Altogether, they highlight that: (1) regional competitiveness depends to a large extent on innovation; (2) one of the innovation sources regards the interactive learning of the company in articulation with its surroundings; and (3) regional innovation networks - that promote the interaction of innovation actors and encourage the cross-fertilization of local knowledge with global knowledge - are crucial for regional development.

Innovation has become central in addressing current territorial dynamics, but also in analyzing the performance of companies. Initially, innovation was associated with the manufacturing industry, due to the R\&D effort. Over time, it was extended to the services sector, considering not only disruptive (radical) innovation, but also incremental innovation. Nevertheless, innovation in rural areas continues to be neglected (Madureira et al. 2013, p. 8), because in such areas, small companies usually use low-tech innovation. Moreover, the activities grounding the economic environment of rural areas continue to be neglected by scholars. For instance, the CIS survey, that frames the European Innovation Scoreboard, excludes agricultural and tourism companies from its scope.

Although neglected in the literature, innovation does exists in rural context. This is evident in European rural areas, as shown by Knickel et al. (2009) and the RAPIDO project (2010), likewise in the Portuguese context by Madureira et al. (2013). Innovation in rural areas is characterised by: (a) the centrality of environmentally sustainable technologies and practices (renewable energies, sustainable agriculture, sustainable tourism); (b) marketing innovation, particularly the creation of marketing networks involving several producers and oriented towards the exploration of new markets; and (c) organizational empowerment innovation of the territory (information and knowledge sharing networks involving education system entities, local development agencies, companies, etc.). These studies give special attention to innovation in rural areas, but also follow the mainstream approach of innovation. In fact, in most economics, literature innovation is related to the productivity and performance of companies, or on the effect for economic growth. This paper intends to contribute to such literature, by following a methodological approach focused on societal innovation (Lehtola \& Ståhle, 2014) in rural areas. As Knickel et al (2009, p. 131) point out, innovation processes can be understood "as the outcome of collaborative networks where information is exchanged and learning processes happen". Thus, innovation does not need to be business-oriented, focused on increasing business productivity. Instead, it can stem from local public policies, centered on the promotion of local development. Even though societal innovation (Lehtola \& Ståhle, 2014) may show similarities with organisational innovation as described on the Oslo Manual, the two should not be considered the same. The epicenter of innovation is not the business organisation, but the organisational model supporting territorial governance (Davoudi, 2008), which should not be confused with government (Stoker, 2019), as further shown. 
Societal innovation has an imprecise boundary with some definitions of social innovation Mulgan (2006, p. 146) defines social innovation as "innovative activities and services that are motivated by the goal of meeting a social need and that are predominantly diffused through organizations whose primary purposes are social. Business innovation is generally motivated by profit maximization and diffused through organizations that are primarily motivated by profit maximization ". In turn, Adams \& Hess (2010, p. 142) argue that "economic innovation, social capital, community strengthening and regional development, together contribute the old ideas which come into new associations in what is being termed social innovation". Both conceptualizations present a common ground with Lehtola \& Ståhle (2014, p. 162) definition of societal innovation: "(1) an organizational or systemic improvement novel of its kind, (2) located at the interface between the state and civil society, and (3) commonly deployed by stakeholders ". The authors also highlight that " societal innovations change the interface of the state and civil society for stakeholder benefit" (Lehtola \& Ståhle, 2014, p. 152). In summary, "a societal innovation introduces a novel economic and / or social improvement to people's everyday life. It brings a (radical or incremental) systemic change to society's structures or modes of operation, and it is legitimated by the majority of societal stakeholders" (Lehtola \& Ståhle, 2014, p. 168). Since the object of study of this paper regards the local development stakeholders in rural context, societal innovation is the theoretical-conceptual framework of this research.

\subsection{The centrality of networking in rural development and the relevance of territorial governance}

If innovation is a key-factor of territorial development, networking dynamics are a critical source of innovation. Thus, the capacity of each territory to innovate and enhance its specificities in the global market depends on the potential of interaction inherent to its economic basis. It also depends on their model of territorial governance, which promotes the interaction among stakeholders of local development. For that, one must understand both the economic basis of rural areas and their model of territorial governance. Regarding the economic basis of rural areas, the following opportunities emerge (Ferrão \& Lopes, 2003; OECD, 2003; 2013; 2018; 2020):

- The exploitation of agricultural production potential, by developing a cluster of agroindustrial activities, and valuing the specificity of traditional local products (e.g., cheese). Such diversification of agricultural production is very important to local competitiveness and sustainability.

- Many rural areas have become tourist destinations, rather than remaining "archaic spaces". The valorisation of the heritage and local culture, as well as rural amenities (OECD, 1994) and environmental tourism, has contributed to altering the economic function of rural areas, converting them into areas of consumption in loco.

- Climate change awareness has opened new opportunities for rural areas. First, the sustainable economy cluster presents itself as the economic pillar of many peripheral rural areas. Second, the environmental quality of such areas has the potential to attract those interested in leaving the city for rural areas. Third, the development of renewable energies represents a big opportunity for the economy of rural areas. Finally, the growing demand for organic food fosters abandoned agricultural soils to be used for agro-organic production.

- The digitalization-driven economy together with a need to find innovative answers to ensure basic services for the population and SMEs in rural areas, as well as the new dynamics of urban-rural articulation, make ICT and innovation essential for the development of rural areas (OECD, 2014; OECD, 2020).

OECD (2020) defines three types of rural regions: (1) rural inside a functional urban area (FUA); (2) rural close to an FUA; (3) rural remote. We argue that the opportunities abovementioned can be different for each type of rural region. The rural close to cities have some advantage to explore all kinds of opportunities, especially in the digitalization-driven economy (more skills available, easy access to specialised services), but also to explore the potential of agricultural production (proximity to consumers). However, remote rural regions have the potential to explore these 
opportunities too, namely those linked to the sustainable economy cluster, and rural tourism. Their natural landscape and environmental quality can be a major advantage to attract people and businesses.

Taking into account the current understanding of rural development, and the pool of opportunities for rural areas, a new policy based on a new model of territorial governance was needed (OECD, 2003; 2006; 2018 and 2020).

Territorial governance is defined as a form of "territorial collective action, based on openness and transparency of the process itself, on cooperation/coordination among actors (horizontally and vertically), and in a framework of a more or less explicit subsidiarity" (Davoudi et al., 2008: 35). This means that the mechanisms of territorial governance should involve not only the community and local organisations, but also public and private organisations with the power to influence innovation, such as universities, companies, and non-governmental organisations. Therefore, territorial governance depends on the organisational capacity of the joint work of such actors within the territory. As pointed out by Stoker (2019), governance cannot be mistaken with government, "governance refers to the development of governing styles in which boundaries between and within public and private sectors have become blurred."(p. 15). Governance refers to the action of local, regional and central public entities, but also the involvement of private sector in the decision-making process. Hence, governance "is about autonomous selfgoverning networks of actors" (p. 20).

This understanding of territorial governance presupposes a place-based policy approach (Barca, 2009; Barca et al., 2012; Vázquez-Barquero, 2010), that ensures: (a) the territorial nature of policies; (b) an integrated approach at the sectoral and territorial levels; and (c) partnership between stakeholders. Following this:

- Public policies must be territorially specified, either in the identification of problems, in the definition of objectives, or regarding the actors who carry out their execution.

- Territorial development policies must be integrated policies, both at the sectoral and territorial levels. "The new paradigm stresses the need for strategies that are contextspecific and maximize policy complementarities. Strategies need to be multi-sectoral, focusing on not just agriculture but also rural industry and services, and on not just rural areas but also rural-urban linkages." (OECD, 2016).

- Policies must be multi-agents, i.e., they must involve not only national, regional, and local authorities, but also private entities and non-governmental organisations.

This territorial approach to development is particularly demanding of the territorial governance dynamics it requires, especially due to the reduced density of actors, characteristic of the most peripheral territories. Hence, rural development policies must be policies centred on the organisational empowerment of rural areas, especially by promoting innovation (business and societal) and networking (intra and inter-territorial) of actors.

In summary, the main theoretical and conceptual changes in rural development policies of the last decades can be defined in three dimensions:

i. Changing the conceptualization of rural. Rural areas began to be conceptualized as territorial entities with their own identity, rather than an agricultural area without identity. Now "the rural is understood not only as a complementary space, but also as interdependent of urban space." (Lopes \& Rodrigues, 2014).

ii. Changing the objectives of rural development policy, by focusing on promoting the competitiveness of local productive systems - and not just agriculture - and synergies among the urban and rural dimensions, overcoming the dichotomous view of both.

iii. Changing the territorial governance model. For institutionalist economists, the existence of adequate institutions (formal and informal) is a fundamental requirement for the success of development policies (Rodriguez-Pose, 2013). Policy-makers should: 
- Promote local economic competitiveness, by valuing the proximity between rural and urban areas, taking advantage of rural market potential for economic sustainable activities.

- Intervene on: (a) the immaterial factors of development, such as the training of human resources; (b) promoting innovation, namely by using ICT; and (c) dynamizing the networking of actors, whether within the territorial business innovation networks, whether at the social innovation level or at the organisational structures that shape territorial development.

- Mobilize local and extra-local actors for projects which are structural for territorial development, reinforcing the organisational scope of the territory, adopting multilevel territorial governance models (Pike et al., 2017) that prevent the handicap of the low density of actors in rural areas.

\section{Three Portuguese innovative experiences in rural development: results}

\subsection{Rural Policy in the Portuguese context}

Regional development policies appeared in Portugal in the late 1960s. They were based on a regional asymmetry between the country's Atlantic coast and the countryside area close to the borders of Spain, the so called "interior". On the one hand, the economy of the Atlantic coast had its ground on industry. On the other hand, agriculture was the main activity of the "interior". This regional asymmetry was also overlapped by an asymmetry between the north and south of Portugal. The south was defined by its large-scale business agriculture, together with a weak intensification of capital. On the north bank of the Tagus river, the agricultural activity was developed almost exclusively by small and very small family farms. Such farms were predominantly for self-consumption and charaterised by an intensified use of labor. Consequently, the rural exodus of the 1960s and 1970s of families from rural areas, mostly from the north, entailed a marked ageing of the population from these areas until today.

The geographical pattern of asymmetries found in the 1960s remains nearly the same nowadays (AD\&C, 2019). Actually, the development of the "Interior" is one of the most prominent priorities of the current government's policies of territorial cohesion. This suggests that, in the last 50 years, rural development policies in Portugal either did not exist at all, or were ineffective in correcting regional development asymmetries (Costa, 2016).

On the continental part of the country, there is no regional level of public administration. The regional administration is structured by the central State and by local authorities. The municipalities of Portugal have greater administrative autonomy than the majority of the municipalities of the EU (OECD, 2020b). But such autonomy is not sufficient to leverage the rural development by itself.

It is within this institutional framework that territorial development policies operate in Portugal. Until the accession to the current EU in 1986, regional policies in Portugal were incipient. After the accession, the EU structural funds have supported successive regional development strategies. Nevertheless, these strategies were always conditioned by Community guidelines. Regarding rural areas, the "old" paradigm (OECD, 2020) has been the main approach, with policymakers taking rural development as a synonym for modernizing agricultural activity. In fact, it was only in the 1992, with the reform of the Common Agricultural Policy, that the principle of multifunctional agricultural and the orientation of sectoral diversification leveraged rural development. Despite this, it was only with the EU's Agenda 2000 that there was an explicit "rural development" dimension embracing territorial interventions for integrated rural development, in line with the Leader approach. However, the measures of community-based "rural development" are integrated into the agricultural policies, which are structured by the norms of the Common Agricultural Policy and supervised by the Ministry of Agriculture. In addition, Portugal, of which $84 \%$ of its area is rural, holds a bit more than $5 \%$ of the funds from community funds to finance the "rural development" component, which is not exclusively for agricultural activity (Gov, 2014). As Carneiro (2005) highlights, Portugal has never been able to define a rural development strategy autonomous from European directives, which always have privileged agricultural activity. 
Indeed, "the bottom-up perspective and the emphasis on the diversification of activities remain the least taken into account" (Carneiro, 2005; p. 18).

Municipalities have been the main driving force behind the development of the rural areas of the country. Until the end of the last century, they have centred their activity on building infrastructures to support local living conditions (e.g., energy and water distribution, sewage system, solid waste collection and treatment, roads). Today, their intervention has shifted to the development of social equipment and policies (e.g., health, education, sport, culture and social support for the elderly and young people). The local economic development dimension of their intervention remains marginal. Instead, the intervention of Portuguese municipalities has been mainly focused on tourism. Two of the case studies presented in this paper (Fundão and Idanha-Nova) are among the main exceptions, which reinforces the relevance and added value of this research.

Madureira et al. (2013) study is central for understanding the meaning of innovation in the Portuguese rural context. It offers an extensive data collection on innovative initiatives in Portuguese rural areas. The authors conducted an exhaustive identification of innovative organizations in these areas, either by a bibliographic and documentary review, or together with business associations, business incubators, banks, universities and municipalities. Among the entities identified as an example of good innovation practices in rural areas, no municipality appears. This clearly reinforces the innovative scope of our research, and the relevance of analysing the three municipalities selected as case studies.

\subsection{Methodology and case studies selection}

The three case studies were chosen due to their location, and their sectoral local development strategies. The selection started by identifying the low-density rural areas of Portugal and, from these, select three geographically close municipalities with similar sociodemographic and morphological characteristics. Then we conducted a document analysis to identify policies prone to be replicated in low-density rural areas. This research included newspapers and institutional sites.

Regarding their location (see Figure 1), the three case studies (the municipalities of Almeida, Fundão and Idanha-a-Nova) are territorial, social and economically similar. All three are located in the "interior" of the country, and are characterised by their historically known family agriculture. This geographical area of Portugal is a well representative of the peripheral low-density rural areas.

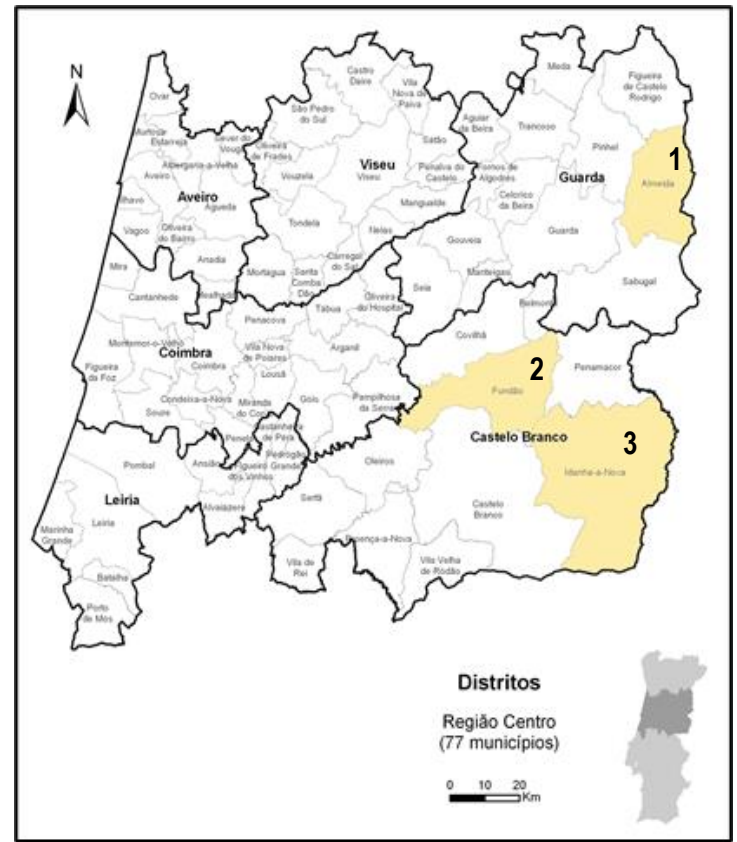

Fig 1. Map of the Central Region of Portugal identifying the three case studies.

Note: 1 - Almeida; 2 - Fundão; 3 - Idanha-a-Nova. Source: Website CCDR-Centro 
The selection of these municipalities was also driven by our goal of comparing different local development strategies, namely: (i) a "classic" strategy centred on tourism (Almeida); (ii) a strategy focused on the valorization of natural resources and the promotion of organic agriculture (Idanha-a-Nova); and (iii) a strategy focused on communication and information technologies (Fundão).

Our second methodological step was to collect information about local strategies and governance dynamics by doing several semi-structured interviews with different local development actors, from the public and private sectors. These were selected accordingly to their power of influence on public opinion, their capacity to promote innovation, and their ability for coordinating territorial policies at the horizontal and vertical levels. Four organisations were selected for each municipality: (i) the City Council; (ii) a Company; (iii) the Local Action Group ${ }^{3}$ (LAG); and (iv) a Local Newspaper or Radio. To cover the supra municipal level of local administration ${ }^{4}$, two entities were also included in the interviews: (i) the Intermunicipal Community of Beiras and Serra da Estrela, which includes the municipalities of Almeida and Fundão; and (ii) the Commission of Coordination and Regional Development (CCRD) of the Centro Region, where the three municipalities are located, which follows the development policy defined by the central government at the regional level.

\subsection{Cases studies' contextualisation and problematisation}

The conceptualisation of "disadvantaged rural areas" by Moreira (2001: 122-123) fits well into the main features of the three municipalities under study: (a) population with low educational level and high demographic ageing; (b) agriculture as the dominant activity, with low levels of productivity and international competitiveness; (c) severe climatic areas, with inadequate infrastructures and far from major decision centres; and (d) production of goods and services on an almost non-existent industrial scale.

These three municipalities are integrated into the geographical space officially classified as "lowdensity territories" urban system, anchored in a traditional economy and with scarce productivity (Almeida, 1994; Mota, 2019). All three are predominantly rural, and have a geographic area much higher than the national average. For instance, Idanha-a-Nova stands out as the $4^{\text {th }}$ largest municipality in Portugal. Over the years, there has been a continuous loss of demographic dynamics and ageing of the population in these municipalities (Bandeira et al., 2014; Vaz \& Nobre, 2019). Except for Fundão, which has a population of 26,495 inhabitants, the remaining municipalities have less than 10,000 inhabitants. Additionally, all three present an educational level below the national average, being Portugal at the bottom of the EU countries. Their major employer activities are family agriculture, local commerce and community-based services, and public administration, revealing a fragile economic basis. Figure 2 summarizes their main characteristics.

\footnotetext{
3 LAG are responsible for the managing community-based/LEADER local development policies financed by EU structural funds.

${ }^{4}$ The supra municipal level follows the regional division used by EU to define regional policies - Nomenclature of Territorial Units for Statistics (NUTS), namely NUTS II and NUTS III.

${ }^{5}$ Deliberation $n^{\circ} 55 / 2015$ of the "Portugal 2020" Interministerial Coordination Commission.
} 


\begin{tabular}{|c|c|c|c|}
\hline Indicators & Almeida & Fundão & $\begin{array}{l}\text { Idanha-a- } \\
\text { Nova }\end{array}$ \\
\hline Resident population, 1960 & 16107 & 47593 & 30418 \\
\hline Resident population, 2001 & 8423 & 31482 & 11659 \\
\hline Resident population, 2019 & 5830 & 26495 & 8043 \\
\hline Pop variation 2019/1960 [\%] & -63.8 & -44.3 & -73.6 \\
\hline Inhabitants / Km², 2019 & 11.3 & 38.0 & 5.7 \\
\hline Population over 65 years old [\%] & 36 & 28 & 41 \\
\hline Minimum distance to Lisbon [km and hours] & $\begin{array}{l}355 \mathrm{~km} \\
(3: 17 \mathrm{~h})\end{array}$ & $\begin{array}{l}262 \mathrm{~km} \\
(2: 26 \mathrm{~h})\end{array}$ & $\begin{array}{l}260 \mathrm{~km} \\
(2: 33 \mathrm{~h})\end{array}$ \\
\hline Tourists overnight stay for 100 hab. 2019 & 343 & 473 & 478 \\
\hline Non-financial enterprises per 100 inhab. 2018 & 11.5 & 11.9 & 11.9 \\
\hline $\begin{array}{l}\text { Local government employment as \% of private salaried } \\
\text { employment, } 2018\end{array}$ & 16.7 & 5.2 & 24.6 \\
\hline Total employment in non-financial enterprises, 2018 & 1128 & 7390 & 1823 \\
\hline$\%$ of employment in agriculture & 22.3 & 14.5 & 30.1 \\
\hline$\%$ of employment in the manufacturing industry & 5.1 & 21.2 & 8.0 \\
\hline$\%$ of employment in retail trade & 18.6 & 21.9 & 14.9 \\
\hline \% salaried business employment (not self-employed) & 81.2 & 81.8 & 62.1 \\
\hline
\end{tabular}

Fig 2. Case studies main indicators. Source: INE, PORDATA, with authors' calculation

\section{The local strategic policies adopted}

We now present a synthesis of the development policy strategy defined by each one of the three City Councils, starting with the municipality of Almeida, followed by Fundão and Idanha-a-Nova.

\subsection{Almeida: promotion of historic heritage and rural tourism}

The political focus of the municipality of Almeida over the last years has been the promotion of historic heritage and rural tourism. Almeida has an imposing and secular fortress, built as a military infrastructure to consolidate the territorial border with Spain. Together with Marvão, Valença and Elvas, the fortress is part of the application of the Fortalezas Abaluartadas to UNESCO World Heritage. The epicentre of the development policy adopted by the municipality is defined by an increase of the cultural offer, such as the creation of the Memorial to Refugees and Consul Aristides de Sousa Mendes, in Vilar Formoso, and the requalification of the Almeida Military Historic Museum and historic villages, such as Almeida and Castelo Mendo.

The strategy that has been adopted is well described by a local actor interviewed:
"I would highlight essentially the investment on the promotion of tourism undertaken by the municipality, both in Almeida and Vilar Formoso, through the promotion of annual events. The siege of Almeida, the hunting and fishing fair, the medieval fair of Castelo Mendo, are already tourist posters that bring many people to the municipality of Almeida. And then there are major events that have also brought visitors, at the level of historic villages, which is a product involving 12 villages in Beira Interior." (Broadcaster of the Local Radio of Almeida)

Among the different networks and partnerships, one of the most important is the partnership between the municipality of Almeida and the Spanish neighbour of Ciudad Rodrigo, which has led to the creation of a cross-border consortium of Walled Cities. Besides the common historical heritage, both municipalities share some public services and participate in international and national fairs on both sides of the border. Moreover, the participation of Almeida in the Network of Jewish of Portugal and in the Network of Historic Villages of Centro Region of Portugal, reinforces the strategy outlined. As the CCDR - Centro Region technician interviewed points out, "Almeida is part of a network that shares cultural activity with the other historic villages". 


\subsection{Fundão: promotion of technological innovation}

In 2015, following the Strategic Plan for Innovation of the Municipality of Fundão (CMF, Edital $\left.n^{\circ} 56\right)$, the City Council placed social and economic innovation at the centre of the municipal political agenda, consolidating the strategy for technological innovation and the creation of an entrepreneurial ecosystem. The project of the Business and Shared Services Centre of Fundão, which started in 2013, was vital for the municipality's social and economic transformation by promoting software development, robotics and business services (Gonçalves et al., 2019).

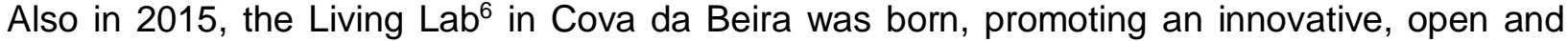
collaborative environment within the local community. It provides "shared workspaces for business incubation and entrepreneurship projects, such as the offer of stores and houses in the old city centre of Fundão, as well as in the Historic Villages of the municipality" (Vaz \& Nobre, 2019: 15).

With a special focus on technological innovation, but also on the intersection between the traditional and the technological sectors, the municipality of Fundão has been attracting not only more individuals related to the technological sector, but also a growing number of national and international companies that settle in the municipality. The training organisation in coding/programming Academia do Código has been an important actor in this strategy, aiming at creating technological hubs and to support companies in the sector. One of its main strengths is its capacity to create and retain value at the local level, and to attract companies, leading some trainees to settle in the region.

An illustration of the success of the strategy pursued is the investment at or near 12 million euros in the municipality, which is expected to create 260 jobs, 200 of which were engineering, in 201920, by the French world leader technological company Altran. According to the company (https://www.altran.com/pt), this investment will allow "the development of innovative projects worldwide in the areas of Intelligent Coding (application of Artificial Intelligence to engineering services software) and Connected Things (developing integration solutions of intelligent systems directed to relevant sectors, such as Automotive, Medical Devices and Connected White Goods)".

A crucial aspect for the development of this policy was the Smart Rural Living Lab's partnership with ENOLL - European Network of Living Labs. It allowed the acquisition of good practices and innovative and relevant services for this type of community (Vaz \& Nobre, 2019). Under the leadership of the City Council, this European network is supported by a wide local and regional network, often with the informal operation, made up of public entities, civic associations, companies, financing entities, universities, schools, research centres, hospital centres and other local development networks.

Rural and Sustainable Tourism is also markedly present in the municipality of Fundão, for example, through the Rota da Cereja or Aldeias de Xisto (see Website, CMF).

\subsection{Idanha-a-Nova: promotion of organic agriculture}

One of the main focus of the City Council of Idanha-a-Nova in the last decade has been the requalification of Herdade Couto da Várzea. This agricultural holding was under the Ministry of Agriculture's network of training and research units, but has been closed and its lands abandoned. In 2009, the City Council signed a contract with the Ministry of Agriculture for Herdade da Várzea, in order to create a rural-based incubator for the development of sustainable agricultural projects (Mateus, Augusto \& Associados, 2017). Also, in 2015, it launched the Recomeçar program, which is based on four pillars: Idanha Vive, Idanha Experimenta, Idanha Made In and Idanha Green Valley, emphasizing entrepreneurship and innovation in agriculture (CMI, Relatório de Contas, 2015). Together with the Recomeçar program, in 2016, the "green" accelerator Idanha Green Valley Food Lab was launched, aiming to support the emergence of start-ups and the development of traditional companies through sustainable solutions (CMI, Relatório de Contas, 2016). In 2018, the municipality of Idanha-a-Nova was the first in Portugal

\footnotetext{
${ }^{6}$ For Vaz \& Nobre (2019:14) Living Lab are "Innovation ecosystems open to ideas and projects that can operate in territorial context and that involve all stakeholders that may be linked to the subject-matters".
} 
to join the International Bio Regions Network, aiming to implement more sustainable development strategies involving the entire community, based on biological and agroecological models (Cabral, 2019). In 2020, the City Council promoted the Organic Farming project, whose objective is the installation of an experimentation centre dedicated to organic agriculture, in Herdade da Várzea. This project involves several companies, namely Sementes Vivas, as well as the National Institute for Agricultural and Veterinary Research (Ministry of Agriculture), the University of Coimbra, the Polytechnic of Castelo Branco, and the Research Institute of Organic Agriculture in Germany.

The City Council has also been looking for new approaches beyond the food sector, such as rural and sustainable tourism, focusing on the development of the 'green economy'. The municipality developed a partnership with the Polytechnic Institute of Castelo Branco - with the Agrarian School, the Management School, and the Agri-Food Support Centre - which is part of the InovCluster - Association of the Agro-industrial Cluster of the Centro Region, in Castelo Branco. This partnership has been an important instrument of the strategy pursued, as stated by a local journalist:

"(...) the small producers of this association of municipalities [INOVCLUSTER], who were a bit lost with the production of blueberries, nuts, almonds, or watermelons, began to receive very important support in scientific terms and even in terms of internationalization to sell their products, (...). " (Local Journalist from Idanha-a-Nova)

As a result, Idanha Green Valley Food Lab has 55 companies established in the municipality, focusing on professional training, research, innovation and agro-biological production. These companies correspond to an investment at or near 10 million euros and the creation of 350 jobs, many of them for graduated young adults. Nowadays, this incubator has 800 hectares of infrastructural agricultural land (divided by Herdade da Várzea, Agri-food Logistics Centre of Ladoeiro and Ribeiro do Freixo). Starting up the Organic Farming project, the incubator should get a new impetus. It is expected to reach a thousand jobs, in a municipality with only 1245 jobs in the business sector.

According to the Mayor of the City Council of Idanha-a-Nova, the effects of the local development policy in the municipality have contributed to strengthening the local business fabric, making it more qualified and more capable to address the challenges of today's world. The political strategy focused on promoting the territorial brand of Idanha-a-Nova has been recognized both nationally and internationally.

Figure 3 summarizes the information regarding the development strategy of the three case studies. 


\begin{tabular}{|c|c|c|c|}
\hline & Almeida & Fundão & Idanha-a-Nova \\
\hline Objectives & $\begin{array}{l}\text { - Economic development } \\
\text { > Retain population } \\
>\text { Job creation }\end{array}$ & $\begin{array}{l}\text { Development of } \\
\text { innovative and } \\
\text { entrepreneurial spirit } \\
\text { Retain population and } \\
\text { attraction of talent } \\
>\text { Job creation } \\
>\text { Human Resource } \\
\text { qualification } \\
>\text { Internationalisation }\end{array}$ & $\begin{array}{l}\text { Economic } \\
\text { development, } \\
\text { innovative and } \\
\text { entrepreneurial spirit } \\
>\text { Retain population } \\
\text { and attraction of } \\
\text { talent } \\
>\text { Job creation }\end{array}$ \\
\hline Measures & $\begin{array}{l}>\text { Historic heritage } \\
\text { requalification } \\
>\text { Cultural animation } \\
>\text { Cross-border thematic } \\
\text { network }\end{array}$ & $\begin{array}{l}\text { Creation of Living Lab, } \\
\text { incubation of start-ups } \\
\text { Attraction of national } \\
\text { and international } \\
\text { companies in the } \\
\text { sector of technology } \\
\text { innovation and } \\
\text { agribusiness } \\
>\text { Inclusion of computer } \\
\text { programming in basic } \\
\text { education }\end{array}$ & $\begin{aligned} &> \text { Creation of a Rural } \\
& \text { Based Incubator } \\
&> \text { Recomeçar } \\
& \text { programme } \\
&>\text { I-Danha Food Lab } \\
&>\text { Organic Farming } \\
& \text { project } \\
&>\text { Bio Regions } \\
& \text { Network }\end{aligned}$ \\
\hline Actors & $\begin{aligned} &> \text { Local authorities } \\
& \text { Docal associations } \\
& \text { D LAG - Castelos do Côa } \\
&>\text { Territórios do Côa - } \\
& \text { Regional Development } \\
& \text { Association } \\
& \text { Distoric Villages } \\
& \text { Network } \\
&>\text { Sustainable Tourism of } \\
& \text { Terras do Lince } \\
& \text { DCDR-Centro Region } \\
& \text { D Portuguese National } \\
& \text { Tourism Institute } \\
& \text { Punicipality of Ciudad } \\
& \text { Rodrigo, in Spain }\end{aligned}$ & $\begin{array}{l}\text { - Local authorities } \\
\text { > Civic associations } \\
\text { (ACICF, G21, } \\
\text { NERCAB) } \\
\text { - Local, regional, } \\
\text { national and } \\
\text { international } \\
\text { companies (Trigger } \\
\text { Systems, Académia } \\
\text { de Código, PT, } \\
\text { YDreams, VitalGreen, } \\
\text { Altram, IBM) } \\
\text { Financing institutions } \\
\text { (Caixa de Crédito } \\
\text { Agrícola), } \\
\text { > Universities and } \\
\text { schools (UBI, Escola } \\
\text { de Turismo e Escola } \\
\text { Profissional do } \\
\text { Fundão, Instituto } \\
\text { Politécnico de Castelo } \\
\text { Branco) } \\
\text { Hospital (CHCB) } \\
\text { > Trade \& Investment } \\
\text { Agency (AICEP) } \\
\text { B Business and Shared } \\
\text { Services Centre of } \\
\text { Fundão Jobcentre - } \\
\text { IEFP } \\
\text { CCDR-Centro Region } \\
\text { D International network } \\
\text { (ENOLL, Portugal } \\
\text { Centre Region } \\
\text { Incubation and } \\
\text { Entrepreneurship } \\
\text { Network) }\end{array}$ & $\begin{array}{l}\text { Local authorities } \\
>\text { Business centre of } \\
\text { Idanha-a-Nova } \\
\text { Ladoeiro Agro-Food } \\
\text { Logistics Centre } \\
>\text { International } \\
\text { Network of Bio } \\
\text { Regions } \\
\text { > ADRACES } \\
>\text { ACTUAR - } \\
\text { Association for } \\
\text { Cooperation and } \\
\text { Development } \\
>\text { CCDR-Centro } \\
\text { Region; } \\
>\text { Polytechnic Institute } \\
\text { of Castelo Branco } \\
>\text { INOVCLUSTER } \\
>\text { European network } \\
\text { EIT Food } \\
\text { National and } \\
\text { international } \\
\text { companies (Canteiro } \\
\text { Silvestre, Sementes } \\
\text { Vivas, grupo Vera } \\
\text { Cruz) }\end{array}$ \\
\hline
\end{tabular}

Fig 3. The strategic policy adopted by each case study. Source: Authors. Based on the information collected in the fieldwork 


\section{Discussion and conclusion}

Looking at the analysis undertaken and the results obtained, the following question arises: to what extent do the policies adopted fit the paradigmatic view of the current strategic guidelines of rural development? Figure 4 provides the necessary information to answer this question, as it summarizes the local development strategies associated with each case study under analysis. Its structure and reading stem directly from the theoretical-conceptual framework presented in section 2 , underpinning the following discussion.

The local development strategy pursued by the three municipalities has as a common denominator: the emphasis on adopting actions aimed to improve the living conditions of its inhabitants. This is not surprising, as the legal framework that defines the powers and competences of local authorities in Portugal relies on such notion. However, Figure 4 makes it clear that Almeida's experience is significantly different from the other two.

Considering its definition as an area bordering Spain, the municipality of Almeida is characterized by a population mainly employed in transport services of goods, local community-based services, and agriculture. The historic-military heritage is one of its most distinctive features, on which the municipality has based its development strategy, drawing on the capacity of tourism to diversify the local economic base. The success of investing in such strategy could stem either from the endogenous potential of the historic heritage or from the favourable context of the global market, given the increasing demand from tourists. Nevertheless, the strategy does not show clear results in terms of job creation, due to not only the conceptually limited and not very innovative strategy, but also to the weakness of its governance model. In general, the strategic approach is more passive than active, and there is a clear deficit on the involvement of different actors, and networking among stakeholders. The list of actors referred by the municipality is long (see Figure 3) but, in addition to the small number of companies involved, there is also a lack of involvement in concrete actions from the multiplicity of actors formally involved in the networks. In other words, networks present themselves as more formal and protocol entities than active entities. Even the Mayor of the City Council of Almeida recognizes the need for greater involvement of the private sector and the local community:
“(...) tourism is increasing every day (...). At most, we would have 80,000 visitors, and we are now reaching 90,000, moving towards 100,000 inhabitants (...), it is the private sector that has to look at these numbers, for the visitors who come to our territory, and make the most of it, and it can create a positive dynamic if there is private investment. " (Mayor of the City Council of Almeida).

The municipalities of Fundão and Idanha-Nova are different from Almeida. In both cases, their strategy relied on the valorisation of endogenous resources, especially of abandoned productive capital, and on the valorisation of the organisational potential already present in the territory. However, this endogenous aspect came together with the valorisation of the opportunities offered by the global market, both in terms of the digital economy cluster (Fundão) and of the growing demand for organic foods (Idanha-a-Nova). In other words, both in Fundão and Idanha-a-Nova, the strategic approach draws on the international literature.

The promotion of local competitiveness claims capacity for innovation, sustained by the combination of endogenous with exogenous potentialities. Fundão's experience is markedly multisectoral, ranging from the digital economy to agriculture, also encompassing the fashion accessories' industry. Regarding Idanha-a-Nova, its strategy is essentially based on agriculture, but on specific forms of agricultural production associated with investment in research and innovation. Even so, in the strategy defined by the municipality of Idanha-a-Nova, the promotion of non-agricultural entrepreneurship, like tourism, has an important role (Entrepreneurs' Workshops of the RECOMEÇAR program), although to a lesser extent regarding the concrete business initiatives that have emerged. 


\begin{tabular}{|c|c|c|c|c|}
\hline DIMENSIONS & KEY ATTRIBUTES & ALMEIDA & FUNDÃO & IDANHA \\
\hline \multirow{12}{*}{ 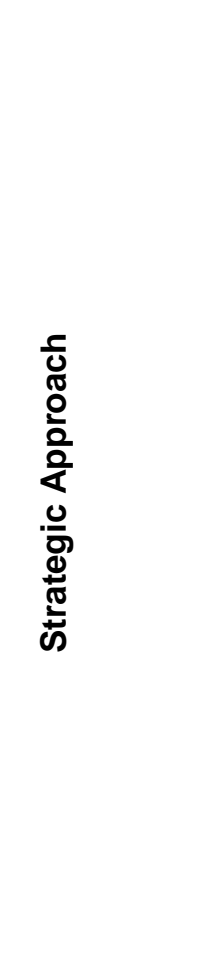 } & Improvement of live conditions & $X X X$ & $X X X$ & $X X X$ \\
\hline & $\begin{array}{l}\text { Pop. attraction based on the rural } \\
\text { amenities }\end{array}$ & & & $X X$ \\
\hline & Valorisation of endogenous potentialities & $X X$ & $x X$ & $X X$ \\
\hline & Valorisation of exogenous potentialities & & $X X X$ & $X X X$ \\
\hline & Competitiveness-cost & $x$ & & \\
\hline & Competitiveness-Innovation & & $X X X$ & $X X X$ \\
\hline & Mono-sectoral strategy & $X X$ & & $X X$ \\
\hline & Multi-sectoral strategy & & $X X X$ & $x$ \\
\hline & Economic base: tourism & $X X X$ & & \\
\hline & Economic base: agro-industrial cluster & & $x$ & $x X$ \\
\hline & $\begin{array}{l}\text { Economic Base: sustainable economy } \\
\text { cluster }\end{array}$ & & & $X X X$ \\
\hline & Economic Base: digital economy cluster & & $X X X$ & \\
\hline \multirow{4}{*}{ 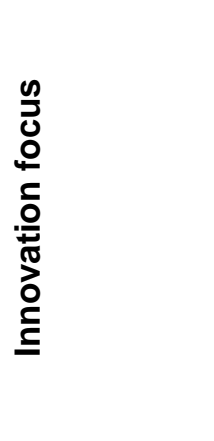 } & Human Resources Qualification & & $X X X$ & $X X X$ \\
\hline & ICT diffusion & & $X X X$ & \\
\hline & $\begin{array}{l}\text { Societal innovation (innovative offer of } \\
\text { collective services, organisation of } \\
\text { stakeholders, etc.) }\end{array}$ & & $X X X$ & $X X X$ \\
\hline & $\begin{array}{l}\text { Diversification of the economic base } \\
\text { (agribusiness, renewable energies, } \\
\text { tourism, etc.) }\end{array}$ & $x$ & & $X X X$ \\
\hline \multirow{5}{*}{ 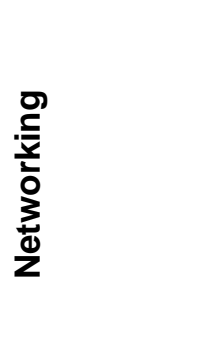 } & Promotion of relational density actors & & $X X X$ & $X X X$ \\
\hline & Urban-rural articulation & $\mathrm{x}$ & $x x$ & $x x$ \\
\hline & Articulation with the global market & $\mathrm{x}$ & $X X X$ & $X X X$ \\
\hline & Dynamic production clusters & & $x X$ & $x X$ \\
\hline & Stimulating innovation networks & & $X X X$ & $X X X$ \\
\hline \multirow{6}{*}{ 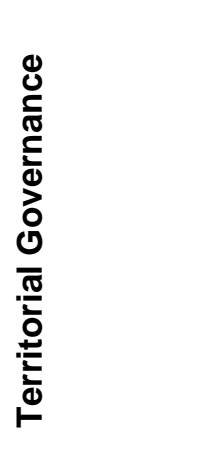 } & Institutional improvement & & $x$ & $\mathrm{x}$ \\
\hline & Organisational training & $x$ & $X X X$ & $X X X$ \\
\hline & Multi-agent policy & & $X X X$ & $X X X$ \\
\hline & Multilevel policies & & $X X X$ & $X X X$ \\
\hline & Sectoral integrated policy & & $x$ & $x$ \\
\hline & $\begin{array}{l}\text { Policy (Intra and inter) territorially } \\
\text { integrated }\end{array}$ & & & \\
\hline
\end{tabular}

Fig 4. Rural policy experiences: analytic matrix. Source: Authors. Based on the information collected in the fieldwork. $\boldsymbol{X}$ denote a weak force; $\boldsymbol{X} \boldsymbol{X} \boldsymbol{X}$ denote a strong force. 
The territorial governance tested in these two municipalities is also in line with the most recent paradigmatic approach. Local authorities have met the vulnerability of the local organisational and institutional texture, with an active and committed attitude of mobilizing local, national and even international (public and private) actors. Particularly noteworthy is the effort to promote networking between regional/national public entities, educational institutions, and companies. Regarding Fundão, the role of informal mediation played by the municipality with the municipality's diaspora and companies of international expression is also relevant. As the Mayor of Fundão referred, networking and multilevel governance were the main keys to the success of the adopted development strategy.

In general, the governance model adopted in Fundão and Idanha-a-Nova resembles what Nunes \& Lopes (2015) call TEI - Territorial Embeddedness Innovation mode, i.e., a way of promoting innovation where the territory provides support for the networks that companies use to pursue innovation. It is important to highlight that, within the econometric essay developed by the authors, the TEI mode provides the companies that adopt it, superior economic performance, compared to the companies using DUI (Doing, Using and Interacting) or STI (Science, Technology and Innovation) as modes of innovation.

A second question emerges from the analysis and the results obtained: to what extent were the policy measures effective for the reinforcement of competitiveness and the promotion of local development?

The processes under analysis are still in an early stage. Hence, it is still premature to make a final assessment of their results. Nevertheless, it was possible to gather some indicators, shown in Figure 5, allowing us to reflect on the effectiveness of the public policies adopted.

These indicators present two different realities: one of the municipality of Almeida, and the other of the two municipalities of Fundão and Idanha-a-Nova. Regarding Almeida, there is an increase in tourist demand, but there is no evidence that its strategy has led to employment growth, or even to an increase in the income of local economic agents. The increase in tourist demand is in line with the general trend of tourism growth. It has not triggered significant business investment in the municipality, and therefore its relationship with the municipality's activity is questionable.

Regarding Fundão and Idanha-a-Nova, findings suggest these are success cases in promoting local development. In Fundão, the municipal strategy saved several businesses from bankruptcy and created others, significantly contributing to the diversification of local economy (agricultural production, textile industry and fashion accessories, nature tourism, and, mainly, digital economy). From a social point of view, it has substantially reduced unemployment, and created qualified employment equivalent to more than $10 \%$ of the wage employment in the business sector. Several of the established companies have competitive strength and an increasing export capacity. In a municipality historically marked by emigration, ageing of the population and depopulation, the City Council points out the current deficit of 400 houses to accommodate those people the local economy is attracting. Certainly, this is a strong indicator of the effectiveness of the strategy adopted in promoting local development. Another indicator is the 700 new jobs, many of them in computer engineering (Mayor of Fundão).

Regarding Idanha-a-Nova, the general evaluation of its policy strategy is clearly positive. First, because the municipality had the capacity to reverse a long historical process of economic and demographic regression. Today, the municipality only has 1250 jobs provided by the business sector, almost $30 \%$ of which have already been created because of the governance dynamics led by the local authority. The initiatives implemented by the City Council: (a) allowed the reuse of abandoned land and equipment; (b) generated value in activities with clear economic competitiveness based on innovation; (c) strengthened the organisational capacity of the territory; and (d) attracted qualified immigrants who came to rejuvenate the economic agents and enrich the municipality's social capital. Besides this, the increasing number of children integrated into the educational system is a clear indicator of the success of the municipal strategy adopted in Idanha-a-Nova. 


\begin{tabular}{|c|c|c|}
\hline Almeida & Fundão & Idanha-a-Nova \\
\hline $\begin{array}{l}\text { 2018: increase of } \\
4 \% \text { of the historic- } \\
\text { heritage and rural } \\
\text { tourism, regarding } \\
2017 \text { (website } \\
\text { CMA) }\end{array}$ & $\begin{array}{l}\text { 2018: the creation of } 68 \text { start- } \\
\text { ups, } 14 \text { of which are ICT } \\
\text { companies (Gonçalves et al., } \\
\text { 2019). } \\
\text { 2018: In the area of new } \\
\text { technologies alone, around } \\
700 \text { jobs were created, } 600 \text { of } \\
\text { which are qualified in the field } \\
\text { of engineering (website CMF) } \\
2018: 38 \% \text { reduction in the } \\
\text { unemployment rate compared } \\
\text { to the previous year (CCDR- } \\
\text { Centro Region, 2018) } \\
\text { The city council of Fundão } \\
\text { won several national and } \\
\text { international awards for } \\
\text { innovation and } \\
\text { entrepreneurship. }\end{array}$ & $\begin{array}{l}>\text { 2018: } 55 \text { companies installed } \\
\text { in the incubator. } \\
\text { 2018: } 350 \text { jobs created. } \\
\text { Increase in the number of } \\
\text { students in the municipality, } \\
\text { from the nursery to Higher } \\
\text { Education (Mota, 2019). } \\
\text { The city council of Idanha-a- } \\
\text { Nova won several national } \\
\text { and international awards } \\
\text { related to 'green economy' } \\
\text { (CMI, Relatório de Contas } \\
\text { 2018). }\end{array}$ \\
\hline
\end{tabular}

Fig 5. Main results of the policies adopted. Source: Authors. Based on the information collected in the fieldwork

Looking at the three case studies altogether, each one has its specificity stemming from its historical past, economic and institutional diversity, and from different approaches to development adopted by each local authority. Therefore, we cannot conclude that there is a general way of promoting local development in the context of low-density rural areas. That was not even our goal. Furthermore, our conclusions are based on a small number of case studies, with an equally small number of interviews. This methodological limitation affects the scope of our conclusions. It would be interesting to define an investigation agenda that: (i) extend the case studies to different countries, even to discuss the differences in the legal framework of municipal authorities; (ii) complete the analysis of interviews with privileged observers with a comprehensive survey of the local population to assess their perception of changes in terms of local development; and (iii) use focus groups to assess the role of local authorities in promoting development.

Despite these limitations, the reflection here presented allows us to retain some conclusions with a general scope. It immediately highlights the difficulty in reversing the vicious circle of (under) development in peripheral rural areas. This is well illustrated by the continuous need of the municipalities of Fundão and Idanha-a-Nova to renew their commitment, as a way of ensuring the success of their strategies.

This paper has also highlighted that there are limits to local action in promoting local development. The case of the municipality of Almeida illustrates this. Despite the difficulties and the danger of failure, the cases of Fundão and Idanha-a-Nova lead us to conclude there is a wide range of possibilities for the bottom-up promotion of local development. The results already obtained by both illustrate well how this type of policies can be effective. Such results seem to be inseparable from the fact that, in these successful cases, a paradigmatic approach to development has been adopted in line with the most recent rural development policy paradigm (as specified in section 2).

Perhaps the most important conclusion to be drawn is that the success of local development policies is inextricably linked to the territorial governance model adopted. In this regard, the case of Almeida could not be more contrasted with those of Fundão and Idanha-a-Nova. The analysis of the last two has evidenced how the key to success relied on the local authority's strategic vision and leadership capacity. First, this strategic vision was aligned with the latest theoretical views, combining endogenous and exogenous potentialities of the territory, and focusing on innovation within a systemic (or cluster) economic approach. Leadership capacity revealed in the promotion of innovation through the networking of local economic actors with the entities of the knowledge system. Second, the leadership capacity was expressed by the establishment of partnerships 
with regional and national public services, as well as by facilitating the access of local agents to the financial resources provided by European investment funds.

One of the political implications of this conclusion is that, in the next programming period for EU rural development policy, it would be desirable to have: (i) a financial reinforcement of resources for rural development not allocated to agricultural activity; (ii) policy instruments aimed at strengthening the organizational and leadership capacity of rural areas, as well as promoting territorial innovation networks of a societal type; and (iii) greater decentralization in the governance of rural development policy, with the involvement of local authorities.

As Sotarauta and Suvinen (2019, p. 1749) point out, "place leadership exists as a specific form of leadership", whose role in the dynamics of development has deserved special attention in the literature of the last decade. Our case studies illustrate precisely how important the role of place leadership can be in the context of multilevel and multi-actor territorial governance. Furthermore, they had the ability to show that local leadership has a high transforming potential. Both cases of Fundão and Idanha-a-Nova represent what Sotarauta and Suvinen (2019) define as "generative leadership", i.e., these municipalities go beyond transformational leadership, not only creating conditions for change but encouraging other actors to innovate and commit themselves to build a collective development process.

In summary, the outreach of the three case studies analysed is limited by their microscale. Hence, their impact on rural development is already conditioned by the absence of effective instruments for articulation with urban areas. We do not intend to infer the cases of Fundão and Idanha-aNova are universally replicable. However, they allow us to conclude that the peripheral rural areas are not condemned to desertification. There is a wide spectrum of opportunities for these areas, if they can bring together a strategic vision of the future and institutional leadership, capable of dynamizing an adjusted model of territorial governance. This is the challenge currently facing rural development policy.

\section{Acknowledgement}

We would like to thank the two anonymous referees for their constructive comments that helped improve this article significantly.

Academic references

[1] Adams, D. \& Hess, M. (2010). Social Innovation and Why it has Policy Significance, The Economic and Labour Relations Review 21(2), 139-156. DOI: 10.1177/103530461002100209.

[2] Asheim, B. T. (2019). Smart specialisation, innovation policy and regional innovation systems: what about new path development in less innovative regions? Innovation: The European Journal of Social Science Research, 32(1), 8-25. DOI: 10.1080/13511610.2018.1491001.

[3] Aydalot, Ph. (1980). Dynamique Spatiale et Développement Inégal. Paris: Economica.

[4] Aydalot, Ph., ed. (1986). Milieux Innovateurs en Europe. Paris: GREMI.

[5] Bandeira, M., Botelho Azevedo, A., Sousa Gomez, C., Tomé, L. P., Mendes, M. F., Baptista, M. I. \& Guardado Moreira, M. J. (2014). Dinâmicas Demográficas e Envelhecimento da População Portuguesa: Evolução e Perspetivas (1950-2011). Lisboa, Fundação Francisco Manuel dos Santos.

[6] Barca, F., McCann, P. \& Rodriguez-Pose, A. (2012). The case for Regional Development Intervention: place-based versus place-neutral approaches. Journal of Regional Science 52(1), 134-152. DOI: 10.1111/j.1467-9787.2011.00756.x.

[7] Benko, G. \& Lipietz, A., eds. (1992). Les régions qui gagnent-districts et réseaux: les nouveaux paradigmes de la géographie économique. Paris: PUF. 
[8] Calatrava, J. (2016). Origin and Evolution of Rural Development Concept and Policies. In Serrão, J. V., Dulce, F., Fernández Prieto, L. \& Santos, R., eds., Old and New Worlds: the global challenges of rural history. Lisbon: ICSTE/IUL.

[9] Capello, R. (2016). What makes Southern Italy still lagging behind? A diachronic perspective of theories and approaches. European Planning Studies, 24(4), 668-686. DOI: 10.1080/09654313.2015.1128402.

[10] Cooke, P. (2001). Regional innovation systems, clusters, and the knowledge economy. Industrial and Corporate Change, 10(4), 945-974. DOI: 10.1093/icc/10.4.945.

[11] Costa, J. (2016). Cinco décadas de políticas de desenvolvimento regional em Portugal. Boletim Regional, Urbano e Ambiental, 14, 73-81. IPEA.

[12] Davoudi, S., Evans, M., Governa, F. \& Santangelo, M. (2008). Territorial governance in the making: approaches, methodologies, practices, Boletín de la A.G.E. 46, 33-52.

[13] Dax, T. \& Fischer, M. (2018). An alternative policy approach to rural development in regions facing population decline, European Planning Studies, 26(2), 297-315. DOI: 10.1080/09654313.2017.1361596.

[14] Fermisson, J. (2000). Problemas da promoção do Desenvolvimento em Portugal. In Territórios Alternativos - Revista 1 (pp. 55-69). Grândola: Instituto de Estudos Superior do Litoral Alentejano.

[15] Ferrão, J. (2000). Relações entre mundo rural e mundo urbano - Evolução histórica, situação atual e pistas para o futuro. Sociologia, Problemas e Práticas, 33, 45-54.

[16] Ferrão, J. \& Lopes, R. (2004). Understanding Peripheral Rural Areas as Contexts for Economic Development. In: Labrianidis, L., ed., The Future of Europe's Rural Peripheries (pp. 31-61). Farnham: Ashgate Publishing.

[17] Ferrão, J. \& Lopes, R. (2003). Zones rurales et capacité entrepreneuriale au Portugal: pratiques, représentations, politiques. Géographie, Économie, Société, 5(2), 119-139. DOI: 10.1016/S1295-926X(03)00038-8.

[18] Ferrão, J. (2015). Ambiente e território: para uma nova geração de políticas públicas com futuro. In Soromenho-Marques, V. \& Trigo Pereira, P., eds., Afirmar o Futuro: Políticas Públicas para Portugal, Vol.2, (pp. 328-336), Lisboa: F. C. Gulbenkian.

[19] Ferreira de Almeida, J., Ferreira do Amaral, J., Borrêgo, A., Capucha, L. \& Farrão, J. (1994). Regiões periféricas: que desenvolvimento? Uma experiência no concelho de Almeida. Lisboa: CIES/ISCTE.

[20] Foray, D. (2015). Smart Specialisation: Opportunities and Challenges for Regional Innovation Policy. London: Routledge.

[21] Füg, F. \& Ibert, O. (2020). Assembling social innovations in emergent professional communities. The case of learning region policies in Germany. European Planning Studies, 28(3), 541-562. DOI: 10.1080/09654313.2019.1639402.

[22] Gonçalves, G., Lopes, D., Fonseca, J. \& Aleixo, B. (2019). Análise Comparativa Internacional do Posicionamento do Sistema Nacional de Inovação. Porto: Agência Nacional de Inovação.

[23] Gurria, A. (2007). Innovation in Rural Areas: An Exception or a Must? Speech presented to the OECD Rural Conference 2007: Innovative Rural Regions: The Role of Human Capital and Technology, Cáceres, Spain. Retrieved from OECD: http://www.oecd.org/innovation/innovationinruralareasanexceptionoramust.htm.

[24] Guterres, A. (2020). Secretary General's Foreword. World Cities Report 2020: The Value of Sustainable Urbanization. Nairobi: UN-Habitat.

[25] Jensen, M. B., Johnson, B., Lorenz, E. \& Lundvall, B. A. (2007). Forms of knowledge and modes of innovation, Research Policy, 36(5), 680-693. DOI: 10.1016/j.respol.2007.01.006. 
[26] Knickel, K., Brunori, G., Rand, S. \& Proost, J. (2009). Towards a Better Conceptual Framework for Innovation Processes in Agriculture and Rural Development. Journal of Agricultural Education and Extension, 15(2), 131-146. DOI: 10.1080/13892240902909064.

[27] Lopes, R. (2001). Competitividade, Inovação e Territórios. Oeiras: Celta Editora.

[28] Lopes, R. \& Rodrigues, J. F. (2014). O Rural e o Urbano no Brasil. [Working Paper]. Lisboa: ICSTE/IUL. DOI: 10.7749/dinamiacet-iul.wp.2014.02.

[29] Madureira, L., Gamito, T. M., Ferreira, D. \& Portela, J. (2013). Inovação em Portugal Rural. Cascais: Principia.

[30] Maillat, D. (1995). Territorial dynamic, innovative milieus and regional policy. Entrepreneurship \& Regional Development, 7, 157-165. DOI: $10.1080 / 08985629500000010$.

[31] Mulgan, G. (2006). The Process of Social Innovation. Innovations: Technology, Governance, Globalization 1(2), 145-162.

[32] Lehtola, V. \& Ståhle, P. (2014). Societal innovation at the interface of the state and civil society. Innovation: The European Journal of Social Science Research, 27(2),152-174. DOI: $10.1080 / 13511610.2014 .863995$.

[33] Moreira, M. B. (2001). Globalização, Agricultura e Zonas Rurais Desfavorecidas, Oeiras: Celta Editora.

[34] Morgan, K. (1997). The learning region: Institutions, innovation and regional renewal. Regional Studies, 31(5), 491-503. DOI: 10.1080/00343409750132289.

[35] Mota, B. (2019). A Problemática dos Territórios de Baixa Densidade: Quatro Estudos de Caso [Mgr. Theses]. Lisboa: ISCTE-IUL.

[36] Nunes, S. \& Lopes, R. (2015). Firm Performance, Innovation Modes and Territorial Embeddedness. European Planning Studies, 23(9), 1796-1826. DOI: 10.1080/09654313.2015.1021666.

[37] Perry, M. (2014). Learning regions as a framework for innovation policy: A review of the issues. Innovation, 16(3), 286-302. DOI: 10.1080/14479338.2014.11081989.

[38] Pike, A., Rodríguez-Pose, A. \& Tomaney, J. (2017). Local and regional development, $2^{\text {nd }}$ ed. London: Routledge.

[39] Porter, M. (1990). The Competitive Advantage of Nations. London: MacMillan Press.

[40] Rodríguez-Pose, A. (2013). Do institutions matter for regional development? Regional Studies, 47(7), 1034-1047. DOI: 10.1080/00343404.2012.748978.

[41] Saxenian, A. L. (1994). Regional Advantage. Cambridge, MA: Harvard University Press.

[42] Schumpeter, J. (1911). The Theory of Economic Development. Cambridge, MA: Harvard University Press.

[43] Sotarauta, M. \& Suvinen, N. (2019). Place leadership and the challenge of transformation: policy platforms and innovation ecosystems in promotion of green growth. European Planning Studies, 27(9), 1748-1767. DOI: 10.1080/09654313.2019.1634006.

[44] Stöhr, W. (1980). Development from Below: The Bottom-up and Periphery-inward Development Paradigm [IIR-Discussion Papers]. Wien: Vienna University of Economics and Business.

[45] Stöhr, W. (1986). Territorial Innovation Complexes. [IIR-Discussion Papers]. Wien: Vienna University of Economics and Business.

[46] Stoker, G. (2019). Governance as theory: five propositions. International Social Science Journal, 68, 227-228. DOI: 10.1111/issj.12189.

[47] Vaz, D. \& Nobre, J. (2019). Inovação Urbana em Territórios Periféricos: Um Balanço Crítico da Região da Beira Interior. Finisterra, 54(111), 5-19. DOI: 10.18055/Finis17102. 
[48] Vázquez-Barquero, A. (1993). Política económica local: la respuesta de las ciudades a los desafios del ajuste produtivo. Madrid: Pirámide.

[49] Vázquez-Barquero, A. (2010). The new forces of Development. Territorial Policy for Endogenous Development. Singapore, World Scientific.

\section{Other sources}

[50] AD\&C (2019). Relatório do Desenvolvimento e Coesão, 2018. Agência para o Desenvolvimento \& Coesão.

[51] Barca, F. (2009). An Agenda for Reformed Cohesion Policy: a place-based approach. [independent report]. EU Commissioner for Regional Policy.

[52] Cabral, L. (2019). "Francisco Sarmento. Revista Adufe: revista cultural de Idanha-a-Nova, $27,20-46$.

[53] Carneiro, I. (2005). O Desenvolvimento Rural em Portugal: caminhos percorridos e por percorrer. Conferência Políticas Públicas para o Desenvolvimento. Universidade dos Acores.

[54] CEMAT (2007). Glossário de Desenvolvimento Territorial, Direção-Geral do Ordenamento do Território e Desenvolvimento Urbano (DGOTDU). Disponível em: https://rm.coe.int/16806f7d5d.

[55] CMF - Câmara Municipal do Fundão. (2015). Edital nº 56. Diário da República, 2a Série № 14 (www.cm-fundao.pt/).

[56] CMI - Câmara Municipal de Idanha-a-Nova (2015). Relatório de Contas 2015.

[57] CMI - Câmara Municipal de Idanha-a-Nova (2016). Relatório de Contas 2016.

[58] CMI - Câmara Municipal de Idanha-a-Nova (2018). Relatório de Contas 2018.

[59] Gov (2014). PDR2020-Programa de Desenvolvimento Rural, 2020. Governo Português.

[60] Mateus, A. \& Associados (2017). O mundo rural e o desenvolvimento económico e social de Portugal, Idanha-a-Nova: Câmara Municipal de Idanha-a-Nova.

[61] OECD (1994). The Contribution of Amenities to Rural Development.

[62] OECD \& Eurostat (1997). The Oslo Manual, OECD, Paris.

[63] OECD (2003). The Future of Rural Policy: from sectoral to place-based policies in rural areas.

[64] OECD (2006). The New Rural Paradigm: Policies and Governance.

[65] OECD (2013). Rural-Urban Partnerships: an integrated approach to economic development.

[66] OECD (2014). Innovation and Modernising the Rural Economy.

[67] OECD (2016). A New Rural Development Paradigm for the 21st Century: a toolkit for developing countries.

[68] OECD (2018). Rural 3.0. A Framework for Rural Development.

[69] OECD (2020). Rural Well-being: Geography of Opportunities, OECD Rural Studies.

[70] OECD (2020b). Decentralisation and Regionalisation in Portugal, OECD, Paris.

[71] RAPIDO (2009). Rural Areas, People \& Innovative Development https://cordis.europa.eu/project/id/44264/reporting. 